\title{
RMS-BASED DAMAGE DETECTION IN CONCRETE BEAMS: NUMERICAL SIMULATIONS
}

\author{
Beata ZIMA, Rafal KĘDRA \\ Gdańsk University of Technology, Faculty of Civil and Environmental Engineering, \\ Department of Mechanics of Materials and Structures, Narutowicza 11/12, 80-233 Gdańsk, Poland, \\ e-mails: beata.zima@pg.edu.pl, rafal.kedra@pg.edu.pl \\ Abstract \\ Image-based damage detection methods using guided waves are well known and widely applied \\ approaches in structural diagnostics. They are usually utilized in detection of surface damages or defects of \\ plate-like structures. The article presents results of the study of applicability of imaging wave-based methods \\ in detection in miniscule internal damage in the form of debonding. The investigations were carried out on \\ numerical models of reinforced concrete beams with varying size of circumferentially oriented debonding \\ between steel rod and concrete block. Maps created using root mean square of measured signals are \\ presented. Moreover, the results were collected for two different excitation frequencies.
}

Keywords: guided waves, damage detection, debonding, reinforced concrete

\section{WYKRYWANIE USZKODZEŃ W BELKACH ŻELBETOWYCH Z WYKORZYSTANIEM RMS: SYMULACJE NUMERYCZNE}

Streszczenie

Metody obrazowania uszkodzeń wykorzystujące propagację fal prowadzonych są dobrze znanym i powszechnie stosowanym narzędziem w diagnostyce konstrukcji. Zwykle są one wykorzystywane do wykrywania uszkodzeń powierzchniowych lub uszkodzeń obiektów płytowych. W artykule przedstawiono analizę możliwości wykorzystania metod obrazowania bazujących na propagacji fal prowadzonych w wykrywaniu niewielkich, wewnętrznych uszkodzeń w postaci rozwarstwienia. Analiza została przeprowadzona $\mathrm{z}$ użyciem modeli numerycznych belek żelbetowych $\mathrm{z}$ obwodowym rozwarstwieniem pomiędzy zbrojeniem a otuliną betonową charakteryzującym się różnymi rozmiarami. Po obliczeniu średniej kwadratowej dla zarejestrowanych sygnałów, wykonane zostały mapy. Ponadto, przedstawiono wyniki dla dwóch różnych częstotliwości wzbudzenia.

Słowa kluczowe: fale prowadzone, wykrywanie uszkodzeń, beton zbrojony

\section{INTRODUCTION}

The nondestructive diagnostics has rapidly developed during last decades. A variety of the possible different approaches allows for applying the most effective method with regard to the kind of investigated object and an analysed problem. The Nondestructive Testing (NDT) is divided into various methods e.g. eddy current [1], ground penetrating radar [2], acoustic emission [3], vibration-based methods [4] or wave propagation based methods like impact-echo [5], ultrasonic [6] and guided wave propagation method [7],[8]. The last method based on guided waves has been extensively studied last years because of waves' insignificant propagation loss and possible application to damage detection. It has become an appealing alternative for an expensive destructive tests or long-time visual inspections. The guided waves' sensitivity to various types of damages causes that they are especially attractive approach for the civil engineering field. Their application allows for monitoring large areas, which are not readily accessible or detecting internal damages like i.e. debondings occurring in composite specimens or reinforced concrete structures, which was presented in many papers. Feng et al. [9] used a broadband chirp signal as excitation to detect delaminations in composite plates. They showed that by observing the disturbance of particular frequency components of chirp-excited Lamb waves, delamination length can be estimated. A novel wave-based method for locating and imaging the contact delaminations in composite plates using Lyapunov damage index was proposed by Liu et al. [10]. Low frequency guided waves for delamination detection in composite laminates were numerically analyzed by Shoja et al. [11]. Examples of the usefulness of guided waves in debonding detection in reinforced concrete structures has been presented among others by Zhu et al. [12] Li et al. [13] and Zima [14]. In the paper [14] it was proved that size or circumferential extent of debonding can be assessed on the basis of a single time-domain signal 
registered at the end of the beam. However, the described methods do not allow for both, precise localization and determining the shape of the debonding, especially when it is large in size. The possible solution might be the image-based methods, which usually allow for visualizing the real position, size and shape of the damage [15][17]. The idea of the use image-based methods consists on appropriate interpretation of the deviations of wave propagation patterns caused by the presence of damage. Their main advantage is the possibility of automation of the diagnostic process and visualization of the exact defect position. An application of image-based methods in structural health monitoring was discussed by Żak et al. [15] They described different strategies of damage detection in plate and shell-like structures using integral mean value (IMV) and root mean square (RMS), which can be calculated on the basis of the time-domain signals registered in the monitored surface according to the following formulas:

$$
\begin{gathered}
\operatorname{IMV}(s)=\frac{1}{t_{2}-t_{1}} \int_{t_{1}}^{t_{2}} s(t) d t \approx \frac{1}{n} \sum_{k=1}^{n} s_{k} \\
\operatorname{RMS}(s)=\sqrt{\frac{1}{t_{2}-t_{1}} \int_{t_{1}}^{t_{2}}\left[s(t)^{2}\right] d t} \approx \sqrt{\frac{1}{n} \sum_{k=1}^{n}\left[s_{k}^{2}\right]}
\end{gathered}
$$

where $s(t)$ is time signal sampled at $n$ points. To create enough detailed damage map, collecting a large number of time-domain signals is required. A perfect solution for monitoring of the significant areas is using a laser scanning vibrometry (LSV). Due to the fact that the scanning process is much more efficient when scanned surface is flat, smooth and laser light is not scattered, the RMS method is usually applied for detection and visualization the damage in plate or shell-like metallic structures with the clearly visible damage in the form of e.g. attached mass, missing bolts hole or damage
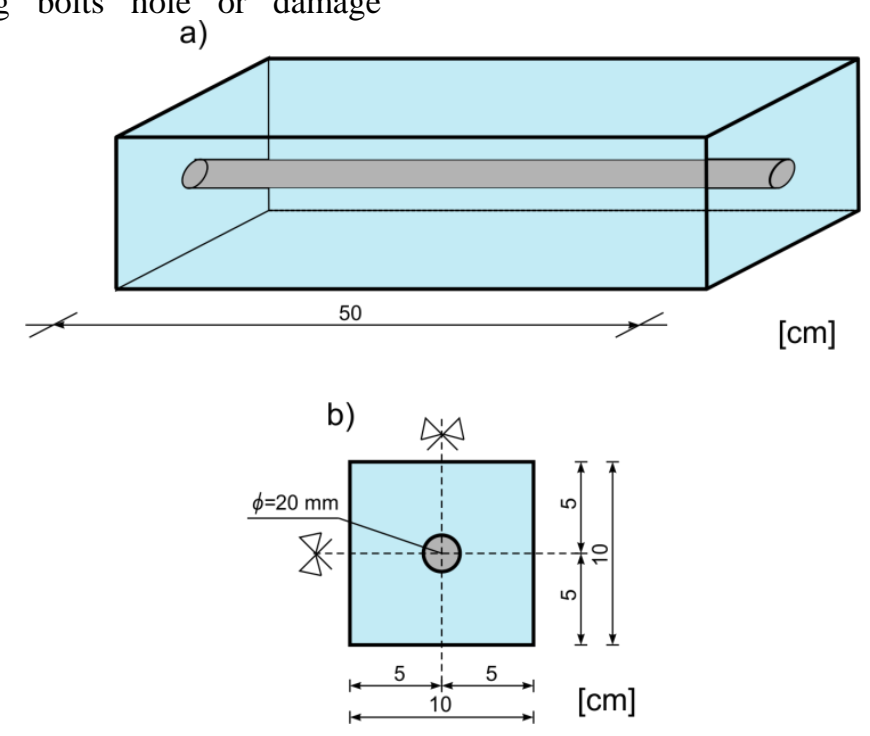

Fig. 1. Scheme of the numerical model: a) geometry of the specimen

\section{Fig. 1. Scheme of the numerical model: a) geometry
and b) geometry of the cross-section}

located near the surface [16]. In the case of reinforced beams with debonding inside the structure, it is impossible to scan the damage directly. Moreover, in the case of plate-like structures only one surface is scanned, while for more complex structural shapes, the key aspect is also the selection of the right area for scanning. Especially, if there is no possibility to scan all surfaces.

The article presents the results of numerical investigation of detection of circumferentially oriented debonding between steel rod and concrete block. The main aim of the paper was an analysis of the possibility of the use image-based inspection in detection of damage located inside the beam-like multi-layered structure. Moreover, the introduced damage was characterized by a very small size. The damage consisted in the lack of connection between the steel core and the cover. The numerical simulations were performed for two different excitation frequencies to present the differences between damage maps obtained for various input parameters.

\section{NUMERICAL RESULTS}

\subsection{Description of numerical model}

The calculations were made for concrete beam with rectangular cross section and single steel rod embedded in the middle of the concrete block in the longitudinal direction. The total length of the beam was $50 \mathrm{~cm}$. The material parameters for concrete were: elastic modulus $E=29 \mathrm{GPa}$, Poisson's ratio $v$ $=0.2$, density $\rho=2306 \mathrm{~kg} / \mathrm{m}^{3}$ and for steel elastic modulus $E=207 \mathrm{GPa}$, Poisson's ratio $v=0.3$, denisty $\rho=7894 \mathrm{~kg} / \mathrm{m}^{3}$. The scheme of the specimen is presented in Fig. 1. 

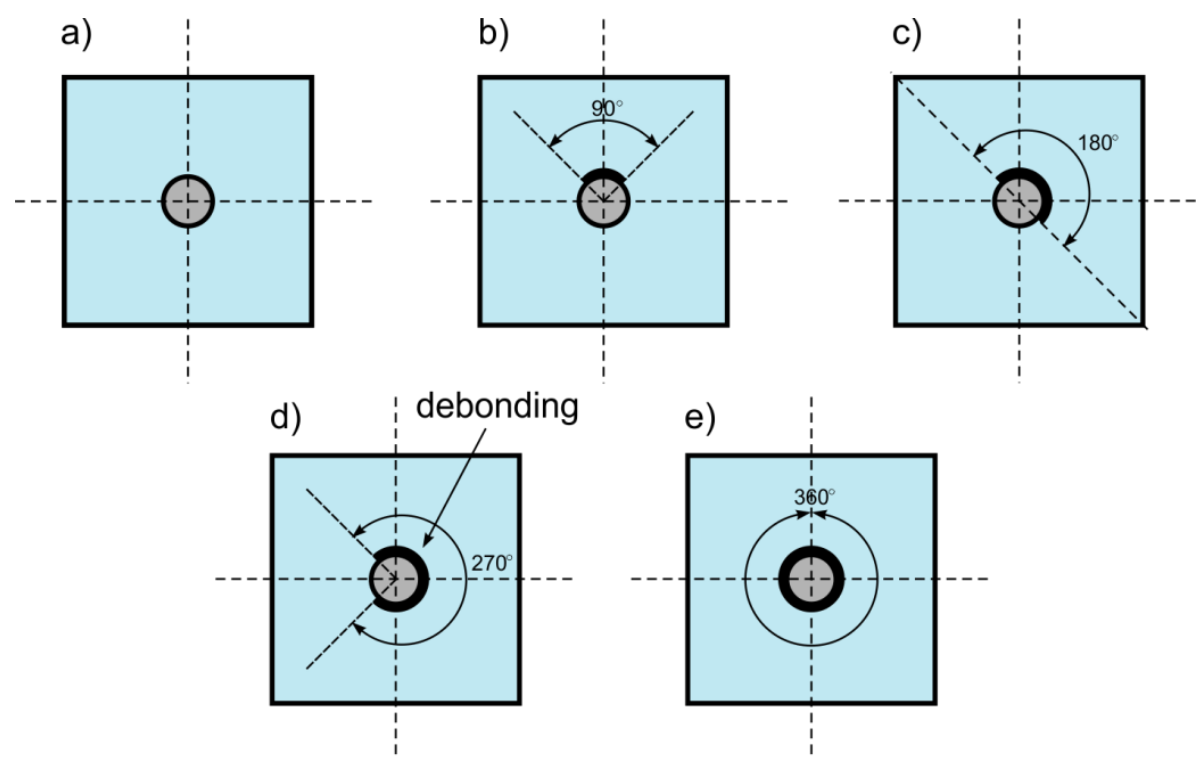

Fig. 2. Geometry of cross-sections of investigated beam models with circumferential debonding equal to a) $0^{\circ}$, b) $90^{\circ}$, c) $180^{\circ}$, d) $270^{\circ}$ and e) $360^{\circ}$

The analysis of wave propagation in reinforced concrete beams with debonding was performed in the commercial program Abaqus by means of the finite elements method. The numerical beam models were performed using eight-node brick finite elements with reduced integration (C3D8R). The size of the finite elements was the same in each model and the maximum size was $2 \mathrm{~mm} \times 2 \mathrm{~mm} \times$ $2 \mathrm{~mm}$. The wave propagation transition problem was solved with the time integration step equal to $10^{-7} \mathrm{~s}$. The length of the integration step and the size of the finite elements were chosen with respect to the wavelength and the time period. The model includes mass proportional damping [18]. The damping coefficients were set on the basis of the comparative analysis with experimentally obtained time-domain signals presented in [14].

Five cases of debonded beam were taken into account (Fig. 2). The beams differ in the debonding size introduced between steel rod and concrete cover. The debonding was introduced along the whole length of the beam, but the circumferential extent was variable and equal to $0,90,180,270$ and 360 degrees, respectively. The connection between steel rod and concrete cover was modelled as tie constrain, while along the debonding no connection has been defined. The time duration of the numerical analysis was equal to $5 \mathrm{~ms}$ until the signal was attenuated and wave motion was not observed. At this time acceleration time-domain signals were registered in each, external node belonging to the side wall of the beam. The acceleration was measured perpendicularly to the wall.

Wave was excited longitudinally along the bar's axis by applying concentrated force in the single node located in the middle of the steel core. The excitation was in the form of 10-cycle sine packet modulated by a Hanning window. The amplitude of the excitation was equal to $1 \mathrm{~N}$. The calculations have been performed for two different, excitation frequencies: 60 and $100 \mathrm{kHz}$. The geometry of the beam models, material parameters and frequencies were chosen behind the experimental studies presented in [14]. Two different excitation frequencies allowed for observing the differences in sensitivity of particular frequencies for damage detection.

\subsection{Wave propagation in beam with debonding}

In the first step, the phenomenon of wave propagation in the specimen with debonding is analysed. For this purpose, the snapshots of propagating disturbance at the start of the beam in the selected time instants obtained numerically are shown in Fig. 3. The first row contains visualization of wave excitation in a fully-bonded rod. Because rod is embedded in concrete block, after excitation wave is transferred into the surrounding medium and spreads with the same velocity in all directions. Wave energy reaches each side wall at the same time (Fig. 3, $t=0.055 \mathrm{~ms}$ ). In each time instant four axes of symmetry can be distinguished.

When debonding of circumferential extent of $90^{\circ}$ is introduced between rod and concrete cover (second row), after excitation wave diffracts at the edges of the damage (Fig. 3b, $t=0.02 \mathrm{~ms}$ ). Along the healthy connection wave is transferred into concrete, while along the debonding there is no energy transfer (Fig. 3b, $t=0.035 \mathrm{~ms}$ ). It can be seen that the disturbance reaches to the side walls of the beam at different times. First, it reaches the walls that lie near undamaged connection. Only later it reaches the upper wall, which lies opposite the debonding. On the basis of this visualization, one can see that debonding affects significantly wave propagation patterns and thus, there should be some differences between signals registered at different walls when debonding develops. 
a)

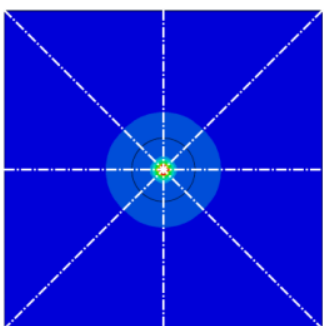

$t=0.02 \mathrm{~ms}$

b)

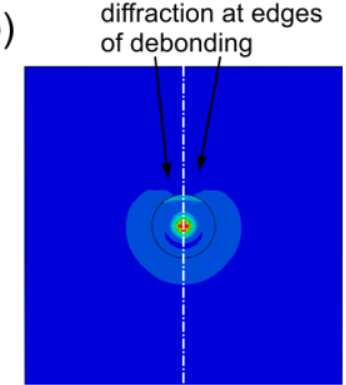

$t=0.02 \mathrm{~ms}$

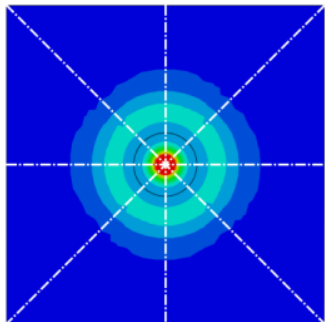

$t=0.035 \mathrm{~ms}$

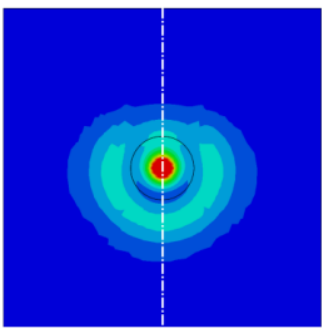

$t=0.035 \mathrm{~ms}$

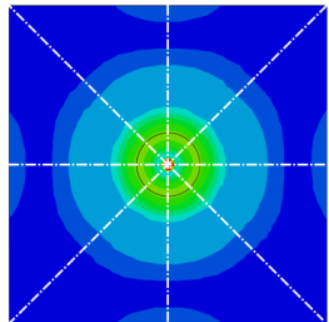

$t=0.0355 \mathrm{~ms}$

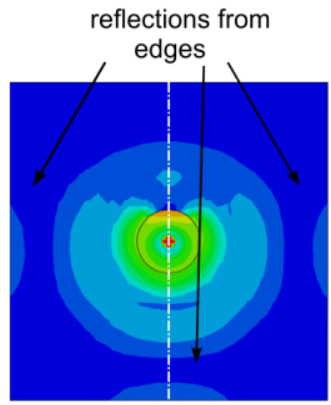

$t=0.0355 \mathrm{~ms}$

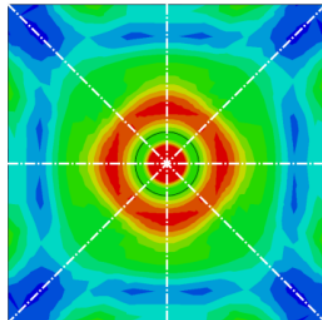

$t=0.055 \mathrm{~ms}$

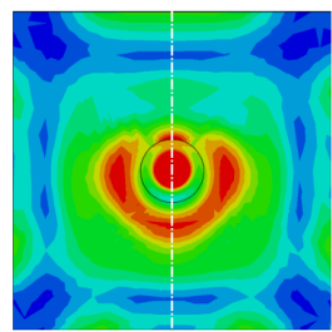

$t=0.055 \mathrm{~ms}$

Fig. 3. Visualization of wave propagation at the start of the a) beam without debonding and $b$ ) beam with debonding of extent $90^{\circ}$

\subsection{Damage maps}

The damage maps have been created using collected time-domain signals. Signals were registered at each node lying on the side surface of the beam. Next, the value of RMS using Eq. (2) was calculated and presented as 2D image using Delaunay triangulation. The results are shown in Fig. 4 and 5. Two different excitation frequencies were taken into account: 60 and $100 \mathrm{kHz}$. Figure 4 presents the results for frequency $60 \mathrm{kHz}$, while the results for $100 \mathrm{kHz}$ are given in Fig. 5 .

For each of five beam models there are four maps corresponding particular side walls. Above the damage maps an additional scheme figures showing for which wall the RMS map was calculated have been added for the clarity.

In the first case of undamaged beam, one can see that four maps are exactly the same (Fig. 4a). Because rod is perfectly connected with concrete cover on the whole of its surface, wave energy leaks with the same intensity in each direction. The same amount of energy reaches each of the four side walls of the beam. The highest values of RMS represented by red color were registered in the middle part of the beam, what suggests that the largest amount of wave energy has propagated there. Because after excitation in the rod wave travels with the same velocity in each direction, it propagates circularly (compare Fig. 3a). The visualization shown in Fig. $3 \mathrm{a}(t=0.055 \mathrm{~ms})$ proves that middle parts of the walls are the first places which wave reaches. It is well known that the longer the distance wave travels, the smaller its amplitude is, because of geometric and material damping. RMS values are the highest in the middle parts of the walls, because there the first reflections from the edges are registered.

When debonding was introduced in the model, RMS maps changed significantly compared to the maps obtained for undamaged beam (Fig. 4b). In maps created for wall 1 and 3, that lie exactly opposite to the debonding, the outline of the rod is clearly visible. The higher values of RMS is caused by wave diffraction at the edges of the debonding (see Fig. 3b, $t=0.02 \mathrm{~ms}$ ). In the case of debonding of circumferential extent of $90^{\circ}$ vertical axis of symmetry exists. The symmetry is visible in the equality of maps obtained for walls 2 and 4, which lies on both sides of this axis.

In the case of beam with debonding of extent equal to $180^{\circ}$ (Fig. 4c) two axes of symmetry can be distinguished and they coincide with diagonals of the cross-section. The consequence is equality of two pairs of images. The maps 1 and 2 and next 3 and 4 are the same.

When only one axis of symmetry can be indicated like in the case shown in Fig. 4d, one pair of similar maps is obtained. The axis of symmetry coincides with horizontal axis and thus, maps 1 and 3 are equal. One can see that in RMS maps calculated for walls 2 and 4, which lied opposite the 
a)

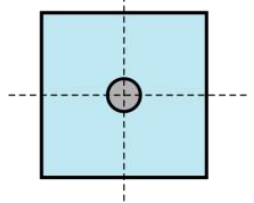

places, where
wave diffracts

b)

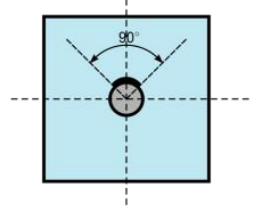

c)

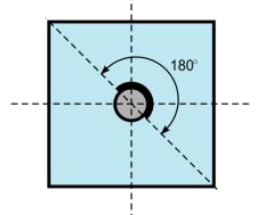

d)

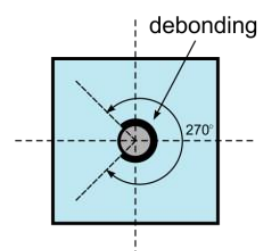

e)

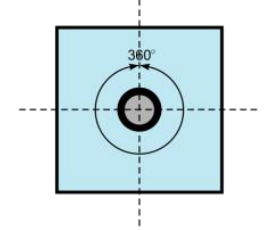

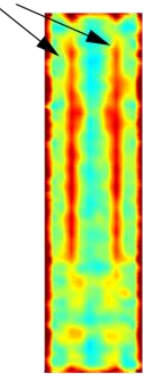
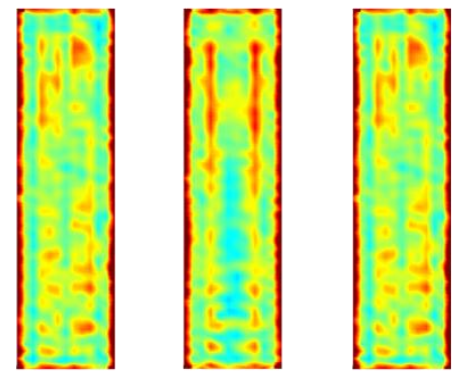

RMS value
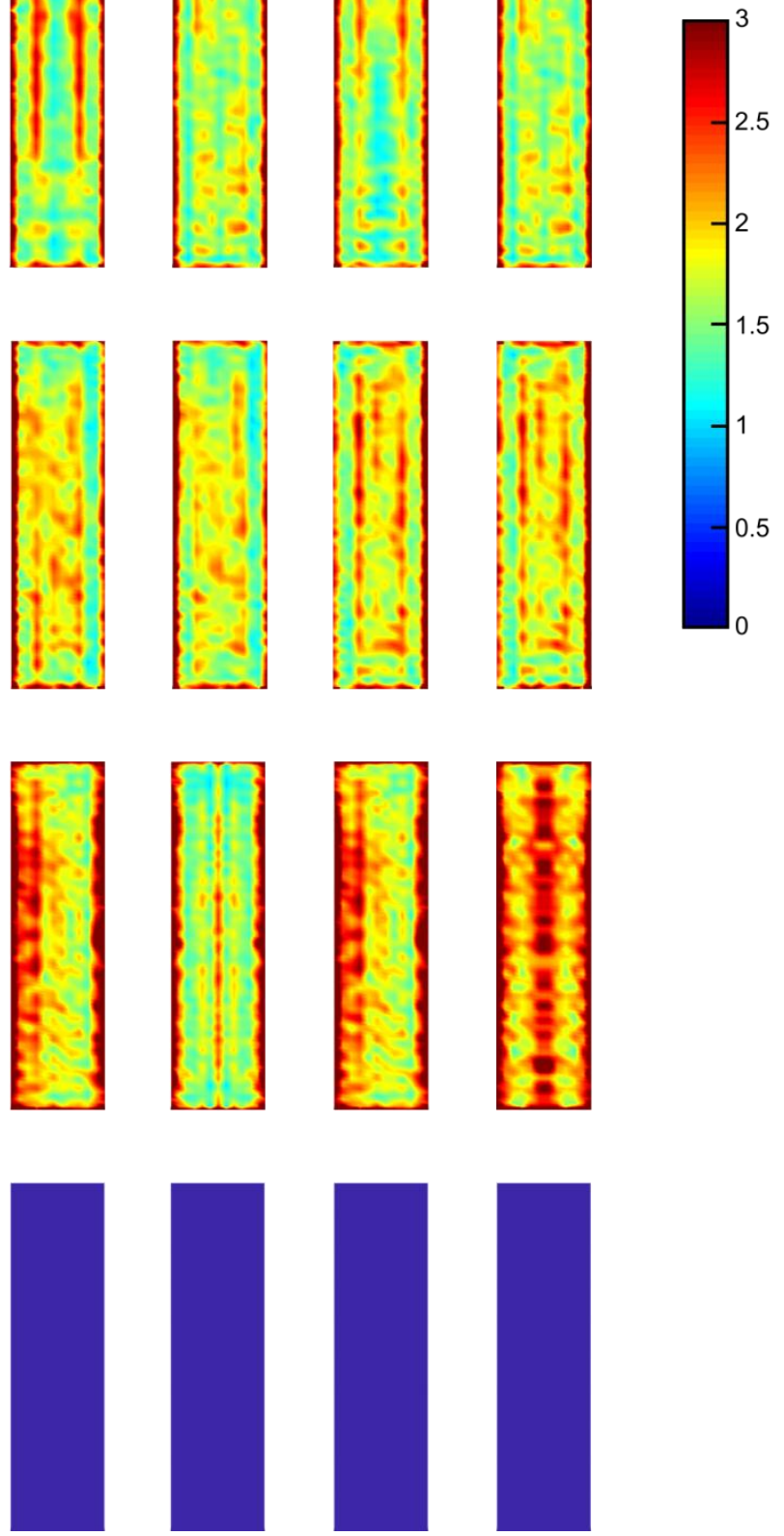

Fig. 4. RMS maps for beam with debonding of extent a) $0^{\circ}$, b) $90^{\circ}$, c) $180^{\circ}$, d) $270^{\circ}$ and e) $360^{\circ}$ for excitation of $60 \mathrm{kHz}$ 
a)

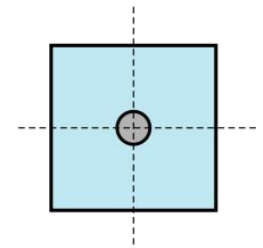

b)

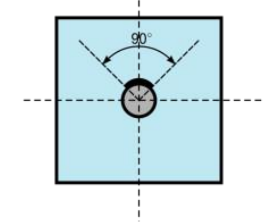

c)

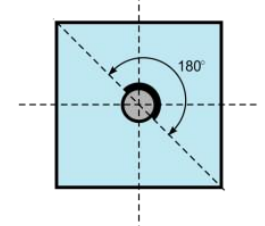

d)

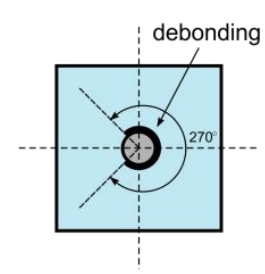

e)

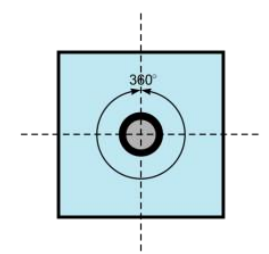

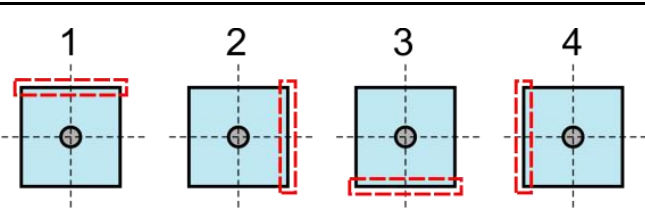
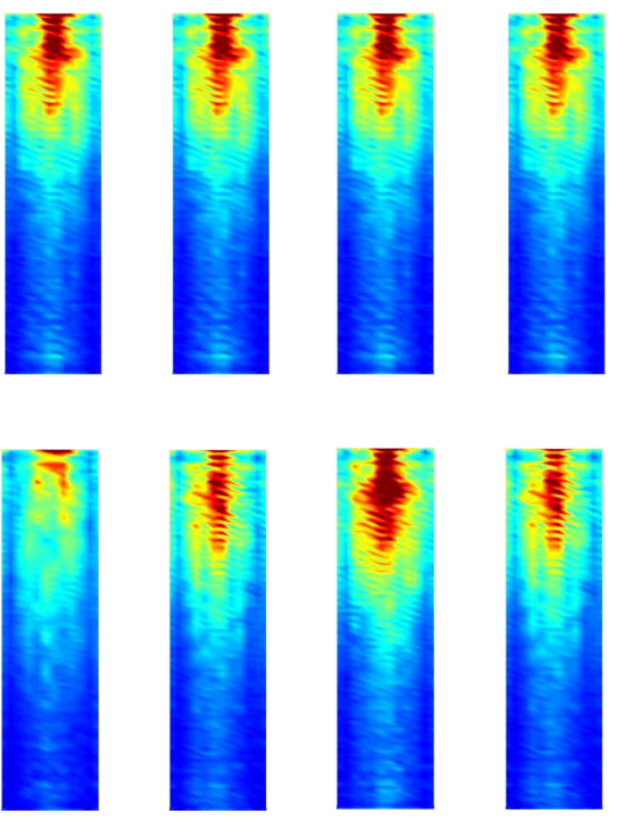

RMS value
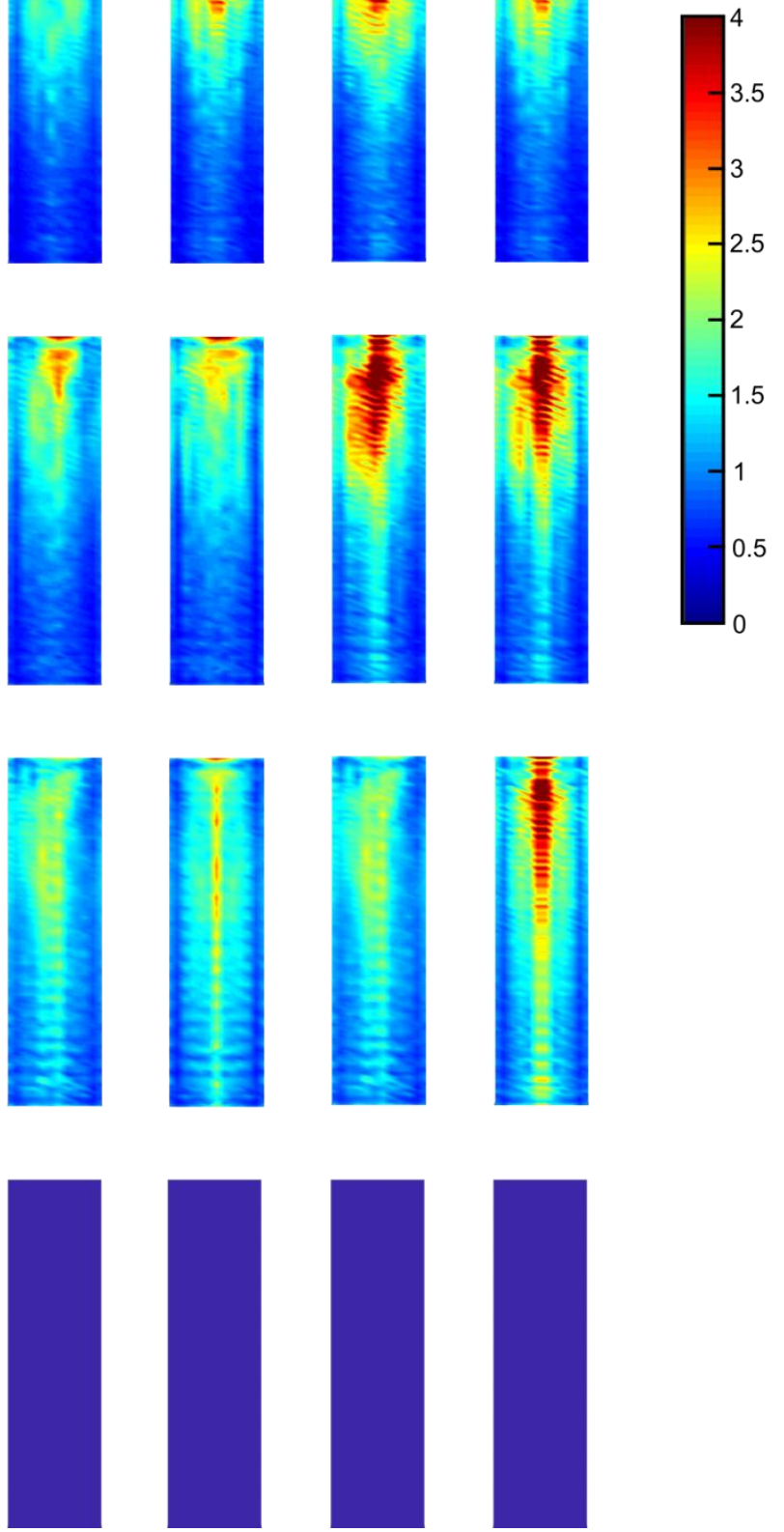

Fig. 5. RMS maps for beam with debonding of extent a) $0^{\circ}$, b) $90^{\circ}$, c) $180^{\circ}$, d) $270^{\circ}$ and e) $360^{\circ}$ for excitation of $100 \mathrm{kHz}$ 
undamaged part of the beam, the areas characterized by the higher value of the RMS value can be indicated. The location of these areas coincides with the longitudinal axis of the rod.

The last case concerned specimen with totally debonded rod - as a wave was excited in separated waveguide, no energy was transferred into surrounding medium and no wave motion was registered at the side surfaces. The RMS values are 0 on the each side surface.

The RMS maps performed in the same way for $100 \mathrm{kHz}$ are presented in Fig. 5. As previously, only in the case of the totally bonded rod, four maps for all beam walls are the same (Fig. 5a). Due to the appearance of the damage, one cannot distinguish four axes of symmetry and the differences between maps in the rest of cases are visible (Fig. 5b-e). Despite the fact that the frequencies 60 and $100 \mathrm{kHz}$ do not differ much, the character of the images created for those two excitations is very different. First significant difference is the location of the areas characterized by high values of RMS. They coincide with the location of the bar (middle part of the beam) and they localized at the end of the specimen, where wave reflects from the opposite beam end. The second difference is the inability to identify the areas where wave was diffracted. On the other hand, in maps for $100 \mathrm{kHz}$ the longitudinal axis of the rod can be easily indicated.

The obtained results suggest that debonding occurrence significantly affects the RMS maps. However, despite the difference between outcomes for varying circumferential extent of the damage, determining the exact damage size and location on the basis of presented results is still a great challenge. Notwithstanding that RMS-based method in this case does not provide comprehensive information about potential damage, presented approach can be useful in confirming the presence of debonding in reinforced concrete beams. In the absence of any damage and longitudinal excitation, all maps performed for particular side surfaces would be identical. Otherwise, significant differences between images obtained for various side surfaces of the same specimen are related with structural fault. Moreover, very low values of RMS can also indicate a poor condition of adhesive connection between core and the cover (see Fig. 4e and 5e). The main disadvantage of the approach based on comparable analysis of maps created for various side surfaces is the necessity of scanning the large surface of the structure.

On the other hand, the results obtained allow to conclude that RMS-based method can be applied in detection various types of damages located inside the structure. The examples are debondings or cracks in multilayered specimens i.e. composite structures. The occurrence of the inside damage affects the wave propagation patterns observed at the outer surface of the structure.
Moreover, the RMS maps can be also used to choose an appropriate location of the sensors attached to the monitored structure. According to Eq. (2) the RMS value is the measure of the signal energy. One can see that in some places the RMS values increase or decrease as a result of debonding development and additional wave diffractions, while in some places in the beams side surfaces the RMS values remain the same regardless the debonding occurrence. The potential system of continuous monitoring would require the small number of permanently attached sensors. It is desirable to locate the sensors, in places where the most significant change in RMS value was observed. Then, even the small change in the monitored RMS value or signal energy would indicate the possible damage development.

\section{CONCLUSIONS}

The article presents the results of numerical investigation partial, circumferentially oriented debonding detection in reinforced concrete beams using guided waves propagation. The main of the paper was an analysis of the possibility of internal, miniscule damage detection on the basis of commonly used RMS-based method. Signals were collected for four side walls of each beam and then damage maps were created. Despite the fact that obtained results do not allow for precise determining the location and shape of the damage, its occurrence can be detected on the basis of the lack of symmetry of results. The results were collected for two different excitation frequencies, which allow to observe the difference in sensitivity of the particular frequency to debonding detection.

The presented results indicate the high potential of RMS-based method in detection of internal damages on the basis of the wave propagation patterns observed on the outer surface of the structure.

\section{REFERENCES}

1. Drobiec , Jasiński R, Mazur W. Accuracy of EddyCurrent and Radar Methods Used in Reinforcement Detection. Materials 2019; 12(7): 1168. https://doi.org/10.3390/ma12071168

2. Lachowicz J, Rucka M. Numerical modeling of GPR field in damage detection of a reinforced concrete footbridge. Diagnostyka 2016; 17(2): 3-8.

3. Goszczyńska B, Świt G, Trąpczyński W, Krampinowska A, Tworzewska J, Tworzewski P. Experimental validation of concrete crack identification and location with acoustic emission method. Archives of Civil and Mechanical Engineering 2012; 12(1): 23-28. https://doi.org/10.1016/j.acme.2012.03.004

4. Mendrok K, Uhl T. Experimental verification of the damage localization procedure based on modal filtering. Structural Health Monitoring 2011; 10(2): 157-171. https://doi.org/10.1177/1475921710373292

5. Garbacz A, Piotrowski T, Courard L, Kwaśniewski L. On the evaluation of interface quality in concrete 
repair system by means of impact-echo signal analysis. Construction and Building Materials 2017; 134: 311-323. https://doi.org/10.1016/j.conbuildmat.2016.12.064

6. Czarnecki L, Garbacz A, Krystosiak M. On the ultrasound assessment of adhesion between polymer coating and concrete substrate. Cement and Concrete Composites 2016; 28(4): 360-369. https://doi.org/10.1016/j.cemconcomp.2006.02.017

7. Mitra M, Gopalakrishnan S. Guided wave based structural health monitoring: A review, Smart Materials and Structures 2016, 25(5): 1-27. https://doi.org/10.1088/0964-1726/25/5/053001

8. Ostachowicz W, Kudela P, Krawczuk M, Żak A. Guided waves in structures for SHM. The Timedomain Spectral Element Method, John Wiley\& Sons Ltd. 2012.

9. Feng B, Ribeiro AL, Ramos HG. A new method to detect delamination in composites using chirp-excited Lamb wave and wavelet analysis. NDT and E International 2018; 100: 64-73. https://doi.org/10.1016/j.ndteint.2018.08.004

10. Liu X, Bo L, Yang K, Liu Y, Zhao Y, Zhang J, Hu N, Deng $\mathrm{M}$. Locating and imaging contact delamination based on chaotic detection of nonlinear Lamb waves. Mechanical Systems and Signal Processing 2018;109: 58-73. https://doi.org/10.1016/j.ymssp.2018.02.041

11. Shoja S, Berbyuk V, Bostrom A. Delamination detection in composite laminates using low frequency guided waves: Numerical simulations. Composite Structures 2018; 203: 826-834. https://doi.org/10.1016/i.compstruct.2018.07.025

12. Zhu XQ, Hao H, Fan Q. Detection of delamination between steel bars and concrete using embedded piezoelectric actuators/sensors. Journal of Civil Structural Health Monitoring 2013; 3: 105-115. https://doi.org/10.1007/s13349-013-0039-2

13. Li J, Lu Y, Guan R, Qu W. Guided waves for debonding identification on CFRP-reinforced concrete beams. Construction and Building Materials 2017; 131: 388-399. https://doi.org/10.1016/j.conbuildmat.2016.11.058

14. Zima B. Guided Wave Propagation in Detection of Partial Circumferential Debonding in Concrete Structures. Sensors 2019; 19(9): 2199. https://doi.org/10.3390/s19092199

15. Żak A, Radzieński M, Krawczuk M, Ostachowicz W. Damage detection strategies based on propagation of guided elastic waves. Smart Materials and Structures 2012;21:1-18. https://doi.org/10.1088/0964-1726/21/3/035024

16. Saravanan JT, Gopalakrishnan N, Rao NP. Damage detection in structural element through propagating waves using radially weighted and factored RMS. Measurement, 2015;3:520-538. https://doi.org/10.1016/j.measurement.2015.06.015

17. Radzieński M, Doliński Ł, Żak A, Ostachowicz W. Application of RMS for damage detection by guided elastic waves. Journal of Physics. Conference Series. 2011;305:1-10. https://doi.org/10.1088/1742-6596/305/1/012085
18. Kudela P, Krawczuk M, Ostachowicz W. Wave propagation modelling in 1D structures using spectral finite elements. Journal of sound and vibration 2007;300: 88-100. https://doi.org/10.1016/j.jsv.2006.07.031

\section{Received 2019-05-30}

Accepted 2019-09-16

Available online 2019-09-17

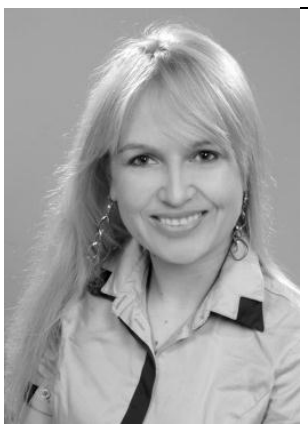

Beata ZIMA, Ph.D. graduated civil engineering at the Faculty of Civil and Environmental Engineering, Gdańsk University of Technology. She mainly deals with diagnostics of structural elements using guided wave propagation.

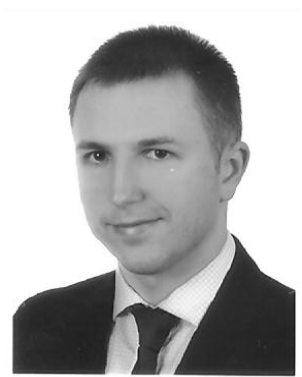

Rafał KĘDRA, M.Sc. graduated civil engineering at Gdańsk University of Technology. Since October 2014 he continues his education as a Ph.D. student. His main interests are modelling of mechanical structures and nondestructive testing. 